\title{
Effects of cyclosporin on collagen induced arthritis in
} mice

\author{
KENJI TAKAGISHI, NOBUHIRO KAIBARA, TAKAO HOTOKEBUCHI, \\ CHIKAFUMI ARITA, MASAHIRO MORINAGA, AND KEN ARAI
}

From the Department of Orthopaedic Surgery, Faculty of Medicine, Kyushu University, 3-1-1, Maidashi, Higashi-ku, Fukuoka, 812 Japan

SUMMARY We have studied the effect of the immunosuppressive agent cyclosporin on collagen induced arthritis in mice. Cyclosporin, when given prophylactically, was capable of suppressing the development of collagen induced arthritis and the immunological response to native type II collagen in a dose dependent manner. Furthermore, treatment with cyclosporin, started on the same day as the booster injection with type II collagen, also resulted in inhibition of development of arthritis and of immunity to collagen. These findings suggest that the time of a booster injection, three weeks after the initial immunisation, might be still within the induction phase of arthritis since reinoculation is required to produce a high incidence of arthritis in mice. In addition, therapeutic treatment with cyclosporin did not affect the clinical course of the disease or the immune response to collagen.

Immunisation with native type II collagen induces inflammatory polyarthritis and immunity to collagen in rats and susceptible strains of mice. ${ }^{1-6}$ The disease, which has been shown to have similarities to human rheumatoid arthritis in many respects, ${ }^{7}$ can be transferred by immune sera from arthritic rats to naive mice ${ }^{8}$ and rats. ${ }^{9}$ Furthermore, we reported previously that a serum concentrate from arthritic rats is capable of inducing arthritis in cyclosporin treated, type II collagen tolerant rats ${ }^{10}$ and congenitally athymic nude rats. ${ }^{11}$ These findings suggest that arthritis in rats and mice might be caused by similar mechanisms, ${ }^{8}$ and that arthritis could be induced by humoral immunity in the absence of cell mediated immunity. " Although pathogenetic mechanisms and the histopathology of collagen induced arthritis in mice are similar to those seen in rats, ${ }^{35}$ there are definite discrepancies in the immune response to collagen between these two species. ${ }^{35}$ In addition, a booster injection and use of complete Freund's adjuvant combined with type II collagen at the time of the primary sensitisation are required to produce a high incidence of arthritis in mice. ${ }^{2}$ The development of arthritis and immune response to collagen

Accepted for publication 1 October 1985.

Correspondence to Dr Kenji Takagishi, Department of Orthopaedic Surgery, Faculty of Medicine, Kyushu University 3-1-1. Maidashi, Higashi-ku, Fukuoka, 812 Japan. are suppressed by pretreating the rat with immunosuppressive agents. ${ }^{12-16}$ The effect of any immunosuppressants on collagen induced arthritis in mice has not been previously reported.

Cyclosporin is a fungal metabolite with potent immunosuppressive properties both in man and animals. Treatment of animals with cyclosporin results in the inhibition of many thymus dependent functions, such as allograft rejection, graft $v$ host rejection, and the development of experimental autoimmune diseases. ${ }^{15-20}$ Recently, we reported that treatment with cyclosporin, begun on the same day as type II collagen immunisation, suppressed the development of collagen induced arthritis in the rat, and that a significant enhancement of arthritis was observed when cyclosporin treatment was started during the immediately preclinical phase of arthritis or after the disease onset. ${ }^{13}$

In this paper we are investigating the effect of cyclosporin on collagen induced arthritis in mice with three different regimens: $(a)$ started on the same day as the primary immunisation, $(b)$ only after a booster injection, and $(c)$ on the established disease. We have found that treatment with cyclosporin, starting concurrently with either the initial or the booster sensitisation, can inhibit the development of arthritis and the immunological response to collagen, but that cyclosporin does not affect the established disease. 


\section{Materials and methods}

M I C E

DBA/1 mice of both sexes, originating from the Jackson Laboratory, Bar Harbor, Maine, were obtained from Seiwa Experimental Animals Ltd, Fukuoka, Japan. They were allowed at least one week to adapt to their environment and were used at 8-10 weeks old, weighing 16-24 g at the start of the present experiment. The same number of mice of each sex were used for each experiment. Animals were fed ad libitum with standard laboratory food and water.

PREPARATION OFTYPEII COLIAGEN AND PRODUCTION OF COLLAGEN INDUCED A RTHRITIS

Type II collagen was isolated and purified from bovine articular cartilage as previously described.' The purity was assessed as described elsewhere. ${ }^{15}$ Lyophilised type II collagen was dissolved in $0 \cdot 1 \mathrm{M}$ acetic acid at a concentration of $2 \mathrm{mg} / \mathrm{ml}(\mathrm{g} / \mathrm{l})$. Complete Freund's adjuvant (CFA) was prepared by adding dried, heat killed Mycobacterium butyricum (Difco Laboratories, Inc., Detroit, MI), which was finely powdered with a mortar and pestle. to incomplete Freund's adjuvant (Difco Laboratories, Inc.) at a concentration of $2 \mathrm{mg} / \mathrm{ml}$. Equal volumes of collagen solution and CFA were emulsified by a homogeniser (Polytron PT 10-35; Kinematica, Lucerne, Switzerland) and kept cold in an ice bath. Collagen induced arthritis was produced by intradermal injection of $0 \cdot 1 \mathrm{ml}$ of the cold emulsion at one site into the base of the tail. Mice were boosted intraperitoneally with $100 \mu \mathrm{g}$ of type II collagen in $0 \cdot 017 \mathrm{M}$ acetic acid on day 21 .

TREATMENT WITH CYCLOSPORIN

Cyclosporin (kindly provided by Sandoz Ltd, Basel, Switzerland) was dissolved in pure olive oil at a concentration of $20 \mathrm{mg} / \mathrm{ml}$ by heating in a water bath to $65^{\circ} \mathrm{C}$. It was freshly prepared every three days. Cyclosporin was given subcutaneously under light ether anaesthesia on the days and at the doses indicated in the text. The dose was adjusted according to the daily body weight. Control mice, while immunised with the same amount of type II collagen, received intradermal injection of olive oil alone. Cyclosporin treated mice and control mice were handled identically for administration of the agent and the solvent.

ASSESSMENT OF ARTHRITIS

Mice were examined daily for seven weeks after the injection of type II collagen to record the day of onset and the severity of arthritis. The lesions of the four paws were each graded from 0 to 4 according to the increasing extent of periarticular erythema: swelling, and joint deformity, as described pres viously. ${ }^{21}$ The maximum possible score was 16 .

IMMUNOASSAY OFIgG ANTIBODYIEVELS T TYPE II COLLAGEN

Blood was routinely collected by retro-orbital bleed ing with a capillary tube on days 21 and 47 . Serurfep samples were removed, heat inactivated at $56^{\circ} \mathrm{C}$ fo $\vec{D}$ $30 \mathrm{~min}$, and stored at $-80^{\circ} \mathrm{C}$ until used. Serum antibodies to type II collagen were measured by the enzyme linked immunosorbent assay technique. Thê methods used were adapted from those of Voller e.9 al. ${ }^{22}$ Briefly, microtitration plates were coated witb $100 \mu \mathrm{l}$ of type II collagen at a concentration of 25 $\mu \mathrm{g} / \mathrm{ml}(\mathrm{mg} / \mathrm{l})$ in coating buffer $\mathrm{pH} 9.6$ and incubate $\mathscr{\mho}^{0}$ overnight at $4^{\circ} \mathrm{C}$. Before assay plates were washeg three times with phosphate buffered saline (PBSP containing $(0 \cdot 05 \%$ Tween 20 . Coating buffer contain ing $1 \%$ bovine serum albumin (BSA) was used te avoid non-specific adsorption. The cuvettes wer washed three times before the addition of a $100 \mu$ aliquot of mouse test serum diluted with PBS-Tweet containing $1 \% \mathrm{BSA}$. The preparation was incubate for two hours at room temperature. After washing three times with PBS-Tween 100 $\mu \mathrm{l}$ of $1: 100\left(\frac{8}{8}\right.$ dilution of alkaline phosphatase conjugated antio mouse IgG (Miles Laboratories. Inc.) was added After incubation for three hours at room tempera ture the plates were again washed three times wit PBS-Tween, and $100 \mu \mathrm{l}$ of $p$-nitrophenyl phosphate substrate (Sigma Chemical Co., St Louis, Mo dissolved in $10 \%$ diethanolamine was added. After incubation at room temperature for $30 \mathrm{~min}$ the reaction was stopped by adding $20 \mu \mathrm{l}$ of $3 \mathrm{M} \mathrm{NaOr} \Phi$ to each well, and the reaction product was. measured by absorbance at $410 \mathrm{~nm}$ by an automate device (Dynatech Laboratories, Inc., Alexandria? VA). The quantity of IgG anti-type II collagerf antibody was expressed as $\mathrm{mg} / 100 \mathrm{ml}$ of serum bD comparison with standard curves obtained from purified mouse anti-type II collagen antibody conN trol. Mouse anti-type II collagen antibody was purified by affinity chromatography on cyanogerp bromide Sepharose 4B using procedures providedo by the supplier (Pharmacia Fine Chemicals, Piscato way, NJ). The procedures used have been describe $\phi$ in detail elsewhere. ${ }^{23}$

RADIOMETRIC EAR IMMUNOASSAY Intradermal, delayed type hypersensitivity (DTH reactions to type II collagen were quantified on das 48 by a radiometric ear immunoassay. Our assay wa $\$$ a modification of that previously described by Vadas et $a l^{24}$ and Rogers et al. ${ }^{25}$ Native type II collagen waş 
dissolved at a concentration of $1 \mathrm{mg} / \mathrm{ml}$ in $0.1 \mathrm{M}$ acetic acid at $4^{\circ} \mathrm{C}$ for $24 \mathrm{~h}$ and then dialysed against cold $0.05 \mathrm{M}$ calcium acetate. $10 \mu \mathrm{l}$ of the test solution was injected intradermally into the right pinna and the same volume of $0.05 \mathrm{M}$ calcium acetate alone into the left. A $2 \mu \mathrm{Ci}$ pulse of $\left[5^{125} \mathrm{I}\right]$ iodo-2'-deoxyuridine $\left(\left[{ }^{125} \mathrm{I}\right] \mathrm{UdR}\right.$, Amersham International plc, Buckinghamshire, England) was given intravenously $10 \mathrm{~h}$ later. The mice were killed $16 \mathrm{~h}$ after the injection of $\left[{ }^{125} \mathrm{I}\right] \mathrm{UdR}$, and the ears were cut off at the hair line. The radioactivity was determined in an automatic gamma counting system (Gamma Trac 1191, Tracor Analytic Inc. Ill.). The radiometric ear index (REI) was expressed as the ratio of radioactivity in the right and left ear samples of an individual mouse. REIs exceeding the mean $\pm 2 \mathrm{SD}$ of values derived by testing 24 naive DBA/1 mice with type II collagen were considered to be significant responses. By these criteria REI $>1.4$ indicated DTH to bovine type II collagen.

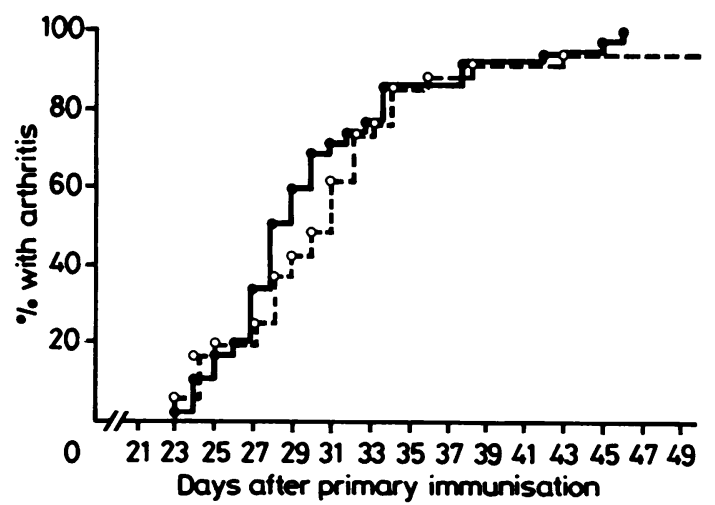

Fig. 1 The incidence and day of onset of arthritis in $D B A / 1$ mice. Male (closed circle) and female (open circle) mice were immunised on day 0 with type II collagen in complete Freund's adjuvant and challenged on day 21 with an intraperitoneal injection of type II collagen alone.
ST A T IST I C S

Continuous variables were analysed by their group means (Student's $t$ test) and dichotomous variables by their proportionate group frequencies ( $\chi^{2}$ test). $p$ Values less than 0.05 were considered to be statistically significant.

\section{Results}

INCIDENCE OF COLLAGEN INDUCED

ARTHRITIS IN DBA/ 1 MICE

To find the incidence and day of onset of arthritis in DBA/1 mice 35 mice of each sex were immunised on day 0 with $100 \mu \mathrm{g}$ of type II collagen in CFA and challenged on day 21 with intraperitoneal injection of $100 \mu \mathrm{g}$ of type II collagen without adjuvant. The results are shown in Fig. 1. An inflammatory polyarthritis developed in $97.1 \%$ of mice. The incidence of arthritis did not depend on the sex of the mice $(100 \%$ in male mice and $94.2 \%$ in female, not significant). The day of onset of the disease was variable: between 23 and 46 days after the initial sensitisation, with a mean of 30.3 days. Sixty of 70 animals developed arthritis by the end of five weeks after primary immunisation. Therefore, therapeutic treatment with cyclosporin was started on day 35 . The mean maximum severity of arthritis in male mice was similar to that seen in female mice $(7 \cdot 2 \pm 3 \cdot 3$ and $6 \cdot 9 \pm 2 \cdot 8$ respectively).

\section{CYCLOSPORIN TREATMENT}

Effect from the day of the primary immunisation with type II collagen

Mice received 14 daily subcutaneous injections of various doses of cyclosporin or olive oil starting on the day of the primary immunisation with type II collagen. Treatment with cyclosporin prevented the development of collagen induced arthritis in a dose dependent manner despite a booster injection (Table 1). A complete prevention of the disease was

Table 1 Effect of cyclosporin treatment (days 0-13) on the development of collagen induced arthritis

\begin{tabular}{|c|c|c|c|c|}
\hline & \multicolumn{3}{|c|}{ Cyclosporin dose $(\mathrm{mg} / \mathrm{kg})$} & \multirow[t]{2}{*}{ Olive oil } \\
\hline & 100 & 50 & 25 & \\
\hline Incidence of arthritis & $0 / 18(0 \%)^{* * *}$ & $4 / 10(40 \%)^{* *}$ & $10 / 10(100 \%)$ & $17 / 18(94 \cdot 4 \%)$ \\
\hline Arthritic indext & - & $3 \cdot 5 \pm 1 \cdot 0^{*}$ & $5 \cdot 9 \pm 1 \cdot 5$ & $7.9 \pm 0.9$ \\
\hline Day of onset $\ddagger$ & - & $37 \cdot 0 \pm 3 \cdot 1$ & $31 \cdot 7 \pm 2 \cdot 4$ & $30 \cdot 8 \pm 1 \cdot 5$ \\
\hline \multicolumn{5}{|l|}{ Antibody level $(\mathrm{mg} / \mathrm{dl}) \S$} \\
\hline 21 days & $7 \cdot 8 \pm 1 \cdot 6^{* * *}$ & $7 \cdot 8 \pm 2 \cdot 2^{* *}$ & $15 \cdot 9 \pm 2 \cdot 1^{*}$ & $48 \cdot 1 \pm 9 \cdot 5$ \\
\hline 47 days & $14 \cdot 4 \pm 2 \cdot 5^{* * *}$ & $39 \cdot 0 \pm 12 \cdot 1^{* *}$ & $67 \cdot 3 \pm 8 \cdot 4$ & $101 \cdot 8 \pm 15 \cdot 3$ \\
\hline DTH skin reaction§ & $1 \cdot 2 \pm 0 \cdot 1^{* * *}$ & $1 \cdot 4 \pm 0 \cdot 1^{*}$ & $1 \cdot 6 \pm 0 \cdot 2$ & $2 \cdot 0 \pm 0 \cdot 2$ \\
\hline
\end{tabular}

${ }^{*} \mathrm{p}<0.05 v$ the oil group; ${ }^{* *} \mathrm{p}<0.01 v$ the oil group; ${ }^{* * *} \mathrm{p}<0.001 v$ the oil group.

tExpressed as the mean of maximum arthritic indices \pm SEM.

$\ddagger$ Based on arthritic mice only (mean \pm SEM).

$\S$ Expressed as the mean $\pm S E M$. 
achieved by treating the animals daily with 100 $\mathrm{mg} / \mathrm{kg} /$ day of cyclosporin, whereas no clear effects were produced by $25 \mathrm{mg} / \mathrm{kg} /$ day of the drug. The effects were accompanied by the inhibition of REI to collagen measured on day 48 and of anti-type II collagen antibody production measured on days 21 and 47. These findings are in accord with our previous report, which suggested that helper $\mathrm{T}$ cell function is mandatory for the production of antitype II collagen antibody. ${ }^{15}$

\section{Effect from the day of a booster injection of type II collagen}

Mice were injected daily with cyclosporin at a dose of $100 \mathrm{mg} / \mathrm{kg}$ for two weeks from the day of a booster injection. It is apparent from a number of in vitro experiments that cyclosporin exerts its effect at a very early stage of $\mathrm{T}$ cell differentiation. ${ }^{26-29}$ Cyclosporin, however, again produced statistically significant suppression of the development of arthritis (Table 2). Moreover, serum antibodies to collagen measured on day 47 and REI to collagen measured on day 48 in cyclosporin treated mice were significantly reduced, though no difference was observed in serum antibodies to collagen measured at the time of a booster injection. A small number of cyclosporin treated animals developed disease, and in those that did the disease was less severe. The onset of the disease in cyclosporin treated mice, however, was not delayed.

\section{Effect on the established disease}

The response of the established disease to cyclosporin treatment was studied. Only arthritic mice received daily cyclosporin therapy for 10 days beginning 35 days after primary immunisation. Cyclosporin did not affect the course of the disease (Fig. 2), nor did its administration alter the immunological response to collagen in this regimen (Table 3).

We did not observe a significant decrease in weight or any other toxic signs in animals receiving

Table 2 Effect of cyclosporin treatment (days 21-34) on collagen-induced arthritis

\begin{tabular}{|c|c|c|c|}
\hline & Cyclosporin & Olive oil & $p$ \\
\hline Incidence of arthritis & $5 / 18(27 \cdot 8 \%)$ & $16 / 18(88.9 \%)$ & $<0.001$ \\
\hline Arthritic index & $3 \cdot 2 \pm 1 \cdot 2$ & $6.9 \pm 0.9$ & $<0.05$ \\
\hline Day of onset & $33 \cdot 8 \pm 3 \cdot 2$ & $32 \cdot 0 \pm 1 \cdot 4$ & NS \\
\hline \multicolumn{4}{|l|}{ Antibody level (mg/dl) } \\
\hline 21 days & $27 \cdot 3 \pm 4 \cdot 2$ & $35 \cdot 0 \pm 5 \cdot 6$ & NS \\
\hline 47 days & $34 \cdot 4 \pm 4 \cdot 3$ & $107 \cdot 7 \pm 15 \cdot 4$ & $<0.001$ \\
\hline DTH skin reaction & $1 \cdot 5 \pm 0 \cdot 1$ & $2 \cdot 0 \pm 0 \cdot 2$ & $<0.05$ \\
\hline
\end{tabular}

Parameters and units are identical to those described in Table 1. NS= not significant .

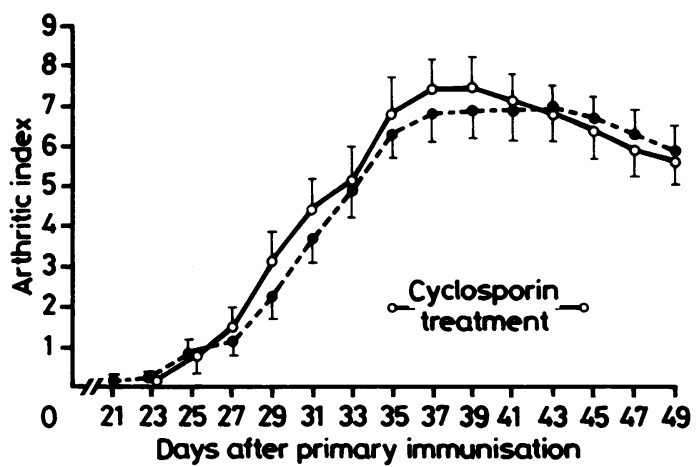

Fig. 2 The severity of arthritis, expressed as a mean arthritic index $\pm S E M$, in groups of 18 arthritic mice begun on day 35 on $100 \mathrm{mg} / \mathrm{kg} /$ day of cyclosporin (open circle) or olive oil alone (closed circle).

Table 3 Effect of cyclosporin treatment (days 35-44) on the established lesion of collagen induced arthritis

\begin{tabular}{lccc} 
& Cyclosporin & Olive oil & $p$ \\
\hline Number of mice tested & 18 & 18 & \\
Arthritic index & $7 \cdot 6 \pm 0 \cdot 8$ & $7 \cdot 8 \pm 0 \cdot 6$ & NS \\
Day of onset & $27 \cdot 0 \pm 1 \cdot 9$ & $27 \cdot 0 \pm 0.9$ & NS \\
Antibody level (mg/dl) & & & \\
21 days & $47 \cdot 7 \pm 10 \cdot 6$ & $51 \cdot 6 \pm 10 \cdot 1$ & NS \\
47 days & $89 \cdot 8 \pm 7 \cdot 5$ & $110 \cdot 9 \pm 12 \cdot 6$ & NS \\
DTH skin reaction & $1 \cdot 8 \pm 0 \cdot 1$ & $2 \cdot 1 \pm 0 \cdot 2$ & NS@ \\
\hline
\end{tabular}

Parameters and units are identical to those described in Table 1.윽 NS $=$ not significant.

this relatively high dosage of cyclosporin in any of the three experiments.

\section{Discussion}

The results presented in this paper show that cyclosporin inhibited the development of collagen? induced arthritis in mice in a dose dependent mannero when the agent was given prophylactically. This effect was accompanied by a marked suppression of antibody production and DTH skin response to typen II collagen. These findings confirm our previous study, which has shown that a 14 day course of cyclosporin treatment, begun on the same day as type II collagen immunisation, suppressed the de velopment of arthritis and the immunological response to type II collagen in rats. ${ }^{15}$ In addition? Brahn and Trentham have shown that the adminis- 0 tration of antithymocyte serum, started one dayd before sensitisation, also suppressed the develop- $-\frac{\pi}{\Phi}$ ment of arthritis in rats. ${ }^{30}$ Moreover, we and other investigators have found that immunisation with 
type II collagen did not induce arthritis or immunity to collagen in congenitally athymic nude rats. ${ }^{11} 31$ On the basis of these findings Brahn and Trentham postulated that collagen induced arthritis is a $\mathrm{T}$ cell dependent disease. ${ }^{30}$ We have recently shown, however, that arthritis can be passively transferred with a serum concentrate to congenitally athymic nude rats ${ }^{11}$ and to cyclosporin treated, type II collagen tolerant rats. ${ }^{10}$ These findings indicate that arthritis may be inducible by humoral immunity alone. Taken together, the present results can be explained by the suppressive effect of cyclosporin on helper $\mathrm{T}$ cells, whose defined function is manifesting the induction of anticollagen antibody formation.

On the basis of the data reported previously cyclosporin acts early in the immune response after exposure to an antigen and affects primary immune events, ${ }^{26-29}$ and treatment is found to be most effective if started simultaneously with an antigen presentation. ${ }^{32}{ }^{33}$ Unique to this study, however, is the demonstration that cyclosporin treatment, begun concurrently with a booster injection, also significantly suppressed the development of arthritis and the immune response to collagen, though the antibody levels at the time of a booster challenge were very low but detectable. Cyclosporin treated mice that did develop arthritis had less severe disease. In contrast with these findings, we have reported that the treatment initiated during the immediate preclinical phase of arthritis in rats was associated with a significant enhancement of the severity of the disease. ${ }^{15}$ The difference in results of the effect of cyclosporin on collagen induced arthritis between rats and mice is not clear; however, histological changes in rats are already evident in the synovium five days after immunisation ${ }^{34}$ and treatment of rats with cyclosporin started during the immediate preclinical phase might be too late to improve the course of the disease. This explanation is supported by the ineffectiveness of antithymocyte serum on collagen induced arthritis in rats when the administration of antithymocyte serum is started five days after immunisation. ${ }^{34}$ On the other hand, a booster injection is required for the development of arthritis in mice, and treatment with cyclosporin initiated on the same day as a booster injection is sufficiently early to suppress the development of arthritis. This preventive effect of cyclosporin on the development of arthritis in mice suggests that the time of a booster injection, three weeks after immunisation, might be within the induction phase of arthritis.

In the last experiment we showed that cyclosporin did not affect the severity of the disease, nor did it alter antibody response and DTH skin reaction, when given therapeutically. It has been previously reported that cyclosporin had a beneficial effect in a patient with relapsing polychondritis ${ }^{35}$ and reversed dermatological plaques in several patients with psoriasis. ${ }^{36}$ In addition, Henderson et al implicated cyclosporin as an antiarthritic agent by investigating only its prophylactic effect on the development of collagen induced arthritis in rats. ${ }^{16} \mathrm{We}$ are concerned, however, by the therapeutic use of cyclosporin based on the data in the present work and in our previous experiments. ${ }^{15}$

In conclusion, cyclosporin was only capable of suppressing the development of collagen induced arthritis in mice when the treatment was started on the same day as either the initial or the booster sensitisation. The results suggest that the time of a booster injection might be within the induction phase of arthritis. Its therapeutic use in mice, i.e. after the onset of clinical features, did not affect the clinical course of arthritis or the immune response to collagen.

We are very grateful to Dr J F Borel and Dr E Wiscott of Sandoz Ltd. Basel, Switzerland, for supplying cyclosporin and also for much helpful advice.

\section{References}

1 Trentham D E. Townes A S. Kang A H. Autoimmunity to type II collagen: an experimental model of arthritis. J Exp Med 1977; 146: $857-68$.

2 Courtenay J S, Dallman M J, Dayan A D, Martin A, Mosedale B. Immunisation against heterologous type II collagen induces arthritis in mice. Nature 1980; 283: 666-8.

3 Trentham D E. Townes A S, Kang A H, David J R. Humoral and cellular sensitivity to collagen in type II collagen-induced arthritis in rats. $J$ Clin Invest 1978; 61: 89-96.

4 Stuart J M. Cremer M A. Kang A H. Townes A S. Collageninduced arthritis in rats: evaluation of early immunologic events. Arthritis Rheum 1979; 22: 1344-51.

5 Stuart J M. Townes A S, Kang A H. Nature and specificity of the immune response to collagen in type II collagen-induced arthritis in mice. J Clin Invest 1982; 69: 673-83.

6 Wooley P H. Luthra H E, Stuart J M, David C S. Type II collagen-induced arthritis in mice. I. Major histocompatibility complex (I region) linkage and antibody correlates. J Exp Med 1981; 154: 688-700.

7 Trentham D E. Collagen arthritis as a relevant model for rheumatoid arthritis: evidence pro and con. Arthritis Rheum 1982: 25: 911-6.

8 Stuart J M, Dixon F J. Serum transfer of collagen-induced arthritis in mice. J Exp Med 1983; 158: 378-92.

9 Stuart J M. Cremer M A. Townes A S, Kang A H. Type II collagen-induced arthritis in rats: passive transfer with serum and evidence that $\operatorname{lgG}$ anticollagen antibodies can cause arthritis. J Exp Med 1982; 155: 1-16.

10 Kaibara N, Morinaga M, Arita C, Hotokebuchi T, Takagishi K. Serum transfer of collagen arthritis in cyclosporin-treated, type II collagen-tolerant rats. Clin Immunol Immunopathol 1985; 35: 252-60.

11 Takagishi K, Kaibara N, Hotokebuchi T, Arita C, Morinaga M, Arai K. Serum transfer of collagen arthritis in congenitally athymic nude rats. $J$ Immunol 1985; 134: 3864-7.

12 Sloboda A E, Birnbaum J E, Oronsky A L, Kerwer S S. Studies on type II collagen-induced polyarthritis in rats: effect of antiinflammatory and antirheumatic agents. Arthritis Rheum 1981: 24: 616-24. 


\section{Takagishi, Kaibara, Hotokebuchi, Arita, Morinaga, Arai}

13 Stuart J M, Myers L K, Townes A S, Kang A H. Effect of cyclophosphamide, hydrocortisone, and levamisole on collagen-induced arthritis in rats. Arthritis Rheum 1981; 24: $790-4$.

14 Phadke K, Carroll J, Nanda S. Effects of various antiinflammatory drugs on type II collagen-induced arthritis in rats. Clin Exp Immunol 1982; 47: 579-86.

15 Kaibara N, Hotokebuchi T, Takagishi K, Katsuki I. Paradoxical effects of cyclosporin A on collagen arthritis in rats. $J$ Exp Med 1983; 158: 2007-15.

16 Henderson B, Stains N A, Burrai I, Cox J H. The anti-arthritic and immunosuppressive effects of cyclosporin on arthritis induced in the rat by type II collagen. Clin Exp Immunol 1984; 57: 51-6.

17 Borel J F, Feurer C, Gubler H U, Stahlin H. Biological effects of cyclosporin A: a new antilymphocytic agent. Agents Actions 1976; 6: 468-75.

18 Nussenblatt R B, Rodrigues M M, Salinas-Carmona M C, Gery I, Cevario S, Wacher W. Modulation of experimental autoimmune uveitis with cyclosporin A. Arch Ophthalmol 1982; 100: 1146-9.

19 King R H M, Craggs R I, Gross M L P. Thompkins C, Thompkins $\mathbf{P}$ K. Thomas $\mathbf{P}$ K. Suppression of experimental allergic neuritis by cyclosporin A. Acta Neuropathol (Berl) 1983; 59: 262-8.

20 Hinrichs D J, Wegman K W, Peters B A. The influence of cyclosporin $A$ on the development of actively induced and passively transferred experimental allergic encephalomyelitis. Cell Immunol 1983; 77: 202-9.

21 Wood F D, Pearson C M. Tanaka A. Capacity of mycobacterial wax $\mathrm{D}$ and its subfractions to induce adjuvant arthritis in rats. Int Arch Allergy Appl Immunol 1969; 35: 456-67.

22 Voller A, Bidwell D E, Bartlett A. Enzyme immunoassay in diagnostic medicine theory and practice. Bull WHO 1976; 53: $55-65$.

23 Kaibara N, Hotokebuchi T, Takagishi K, et al. Pathogenctic difference between collagen arthritis and adjuvant arthritis. $J$ Exp Med 1984; 159: 1388-96.

24 Vadas M A, Miller J F A P, Gamble J, Whitelaw A. A radioisotopic method to measure delayed type hypersensitivity in the mouse. Studies in sensitised and normal micc. Int Arch Allergy Appl Immunol 1975; 49: 670-92.

25 Rogers M P. Trentham D E, McCune W J, et al. Effect of psychological stress on the induction of arthritis in rats. Arthritis Rheum 1980; 23: 1337-42.

26 Larsson E L. Cyclosporin A and dexamethasone suppress T cell responses by selectively acting at distinct sites of the triggering process. J Immunol 1980; 124: 2828-33.

27 Palacios R, Moller G. Cyclosporin A blocks receptors for HLADR antigens on $T$ cells. Nature 1981; 290: 792-4.

28 Bunjes D, Hardt C. Rollinghoff M, Wagner H. Cyclosporin A mediates immunosuppression of primary cytotoxic $T$ cell responses by impairing the release of interleukin 1 and interleukin 2. Eur J Immunol 1981; 11: 657-61.

29 Hess A L. Tutschka P J, Santos G W. Effect of cyclosporin A on human lymphocyte responses in vitro. II. Induction of specific alloantigen unresponsiveness mediated by a nylon wool adherent suppressor cell. J Immunol 1981; 126: 961-8.

30 Brahn E. Trentham D E. Effect of antithymocyte serum on collagen arthritis in rats: evidence that $T$ cells are involved in its pathogenesis. Cell Immunol 1984; 86: 421-8.

31 Klareskog L, Holmdahl R, Larsson E, Wigzell H. Role of T lymphocytes in collagen II induced arthritis in rats. Clin Exp Immunol 1983: 51: 117-25.

32 Homan W P. Fabre J W, Williams K A, Millard P R, Morris $P$ J. Studics on the immunosuppressive properties of cyclosporin A in rats recciving renal allografts. Transplantation 1980; 29: 361-6.

33 Morris P J. Cyclosporin A. Transplantation 1981; 32: 349-54.

34 Caulficld J P. Hein A, Dyncsius-Trentham R, Trentham D E. Morphologic demonstration of two stages in the development of type II collagen-induced arthritis. Lab Invest 1982; 46: 321-43.

35 Svenson K L G, Holmdahl R, Klareskog L, et al. Cyclosporin A trcatment in a case of relapsing polychondritis. Scand $J$ Rheumatol 1984; 13: 329-33.

36 Graf U, Marbet U, Miller W, Thicl G. Cyclosporin AWirkungen und Nebenwirkungen bei der Behandelung der chronischen Polyarthritis und der Psoriasisarthritis. Immun Infekt 1981; 9: 20-8. 